\title{
Functional Imaging of Oxidative Stress with a Novel PET Imaging Agent, ${ }^{18}$ F-5-Fluoro-L-Aminosuberic Acid
}

\author{
Jack M. Webster ${ }^{1}$, Christine A. Morton ${ }^{1}$, Bruce F. Johnson ${ }^{1}$, Hua Yang ${ }^{2}$, Michael J. Rishel ${ }^{1}$, Brian D. Lee ${ }^{1}$, Qing Miao ${ }^{2}$, \\ Chittari Pabba ${ }^{1}$, Donald T. Yapp ${ }^{3,4}$, and Paul Schaffer ${ }^{2}$ \\ ${ }^{I}$ Diagnostics and Biomedical Technologies, GE Global Research, Niskayuna, New York; ${ }^{2}$ Nuclear Medicine Division, TRIUMF, \\ Vancouver, British Columbia, Canada; ${ }^{3}$ Division of Pharmaceutics and Biopharmaceutics, Faculty of Pharmaceutical Sciences, \\ University of British Columbia, Vancouver, British Columbia, Canada; and ${ }^{4}$ Experimental Therapeutics, BC Cancer Agency, \\ Vancouver, British Columbia, Canada
}

Glutathione is the predominant endogenous cellular antioxidant, playing a critical role in the cellular defensive response to oxidative stress by neutralizing free radicals and reactive oxygen species. With cysteine as the rate-limiting substrate in glutathione biosynthesis, the cystine/glutamate transporter $\left(\right.$ system $\mathrm{x}_{\mathrm{c}}^{-}$) represents a potentially attractive PET biomarker to enable in vivo quantification of $x_{c}^{-}$activity in response to oxidative stress associated with disease. We have developed a system $x_{c}{ }^{-}$substrate that incorporates characteristics of both natural substrates, L-cystine and L-glutamate (L-Glu). L-aminosuberic acid (L-ASu) has been identified as a more efficient system $x_{c}{ }^{-}$substrate than $L-G l u$, leading to an assessment of a series of anionic amino acids as prospective PET tracers. Herein, we report the synthesis and in vitro and in vivo validation of a lead candidate, ${ }^{18} \mathrm{~F}-5$-fluoro-aminosuberic acid $\left({ }^{18} \mathrm{~F}-\mathrm{FASu}\right)$, as a PET tracer for functional imaging of a cellular response to oxidative stress with remarkable tumor uptake and retention. Methods: ${ }^{18} \mathrm{~F}-\mathrm{FASu}$ was identified as a potential PET tracer based on an in vitro screening of compounds similar to L-cystine and L-Glu. Affinity toward system $\mathrm{x}_{\mathrm{C}}{ }^{-}$was determined via in vitro uptake and inhibition studies using oxidative stress-induced EL4 and SKOV-3 cells. In vivo biodistribution and PET imaging studies were performed in mice bearing xenograft tumors (EL4 and SKOV-3). Results: In vitro assay results determined that L-ASu inhibited system $\mathrm{x}_{\mathrm{c}}{ }^{-}$as well as or better than L-Glu. The direct comparison of uptake of tritiated compounds demonstrated more efficient system $\mathrm{X}_{\mathrm{c}}{ }^{-}$uptake of L-ASu than L-Glu. Radiosynthesis of ${ }^{18} \mathrm{~F}-\mathrm{FASu}$ allowed the validation of uptake for the fluorine-bearing derivative in vitro. Evaluation in vivo demonstrated primarily renal clearance and uptake of approximately 8 percentage injected dose per gram in SKOV-3 tumors, with tumor-to-blood and tumor-to-muscle ratios of approximately 12 and approximately 28 , respectively. ${ }^{18} \mathrm{~F}-\mathrm{FASu}$ uptake was approximately 5 times greater than ${ }^{18} \mathrm{~F}-\mathrm{FDG}$ uptake in SKOV-3 tumors. Dynamic PET imaging demonstrated uptake in EL4 tumor xenografts of approximately 6 percentage injected dose per gram and good tumor retention for at least $2 \mathrm{~h}$ after injection. Conclusion: ${ }^{18} \mathrm{~F}-\mathrm{FASu}$ is a potentially useful metabolic tracer for PET imaging of a functional cellular response to oxidative stress. ${ }^{18} \mathrm{~F}$-FASu may provide more sensitive detection than ${ }^{18} \mathrm{~F}-\mathrm{FDG}$ in certain tumors.

\footnotetext{
Received May 28, 2013; revision accepted Nov. 11, 2013.

For correspondence or reprints contact: Jack M. Webster, GE Global Research, One Research Circle, K1-5D57, Niskayuna, NY 12309.

E-mail: webster@research.ge.com

Published online Feb. 27, 2014.

COPYRIGHT $\odot 2014$ by the Society of Nuclear Medicine and Molecular Imaging, Inc.
}

Key Words: oxidative stress; PET; functional imaging; tumor imaging; ${ }^{18} \mathrm{~F}$

J Nucl Med 2014; 55:657-664

DOI: 10.2967/jnumed.113.126664

\section{O} PET imaging agents to visualize tumors, including anti-1-amino$3-{ }^{18} \mathrm{~F}$-fluorocyclobutyl-carboxylic acid, $O-\left(2-{ }^{18} \mathrm{~F}\right.$-fluoroethyl)-tyrosine, $6-{ }^{18} \mathrm{~F}$-fluoro-L-dopa, and ${ }^{18} \mathrm{~F}-(4 R)-4$-fluoro-L-glutamine $(1-4)$. These agents rely primarily on the neutral amino acid transporter systems L (large neutral amino acid preferring) and ASC (alanineserine-cysteine preferring) for tumor uptake (5). By comparison, the most commonly used PET tracer, ${ }^{18} \mathrm{~F}$-FDG, uses an increase in glucose uptake that feeds increased tumor metabolism. Although the molecular mechanisms of glucose and amino acid uptake may differ, they both target augmentations to cellular transport systems that enable higher demands for energy production and protein synthesis required for unrestrained proliferation.

System $\mathrm{x}_{\mathrm{c}}{ }^{-}$was first described by Bannai and Kitamura as a sodium-independent amino acid transport system with a very narrow natural substrate binding profile $(6,7)$, especially when compared with other known transporters (8). This cystine/glutamate transporter is a dimeric cell surface transporter that consists of a heavy chain subunit $(4 \mathrm{~F} 2 \mathrm{hc}$ ) for membrane trafficking and $\mathrm{xCT}$, the smaller subunit that imparts substrate specificity. The $\mathrm{xCT}$ subunit maintains very low basal expression in most normal tissues, with the exception of the brain, pancreas, spleen, and thymus, but is universally upregulated as cells respond to oxidative stress (9). The ubiquitin-ligase protein KEAP1 acts as a biosensor for oxidative stress through a reactive oxygen species-induced covalent modification of an active site cysteine residue. Modified KEAP1 can no longer facilitate the proteasomal degradation of the transcription factor Nrf2, resulting in the expression of several genes with antioxidant response element (ARE) promoters, including $\mathrm{xCT}(10-13)$ as shown in Figure 1. The resulting enhanced cystine influx, and intracellular reduction to cysteine, meets the increased demand for this rate-limiting precursor of glutathione synthesis. Therefore, system $\mathrm{x}_{\mathrm{c}}{ }^{-}$imaging can provide functional information about the cellular response to oxidative stress in a tumor or organ, operating as an in vivo reporter for ARE activation.

Targeting system $\mathrm{x}_{\mathrm{c}}{ }^{-}$for PET tracer development has potential advantages over other amino acid transporters. First, detection of 


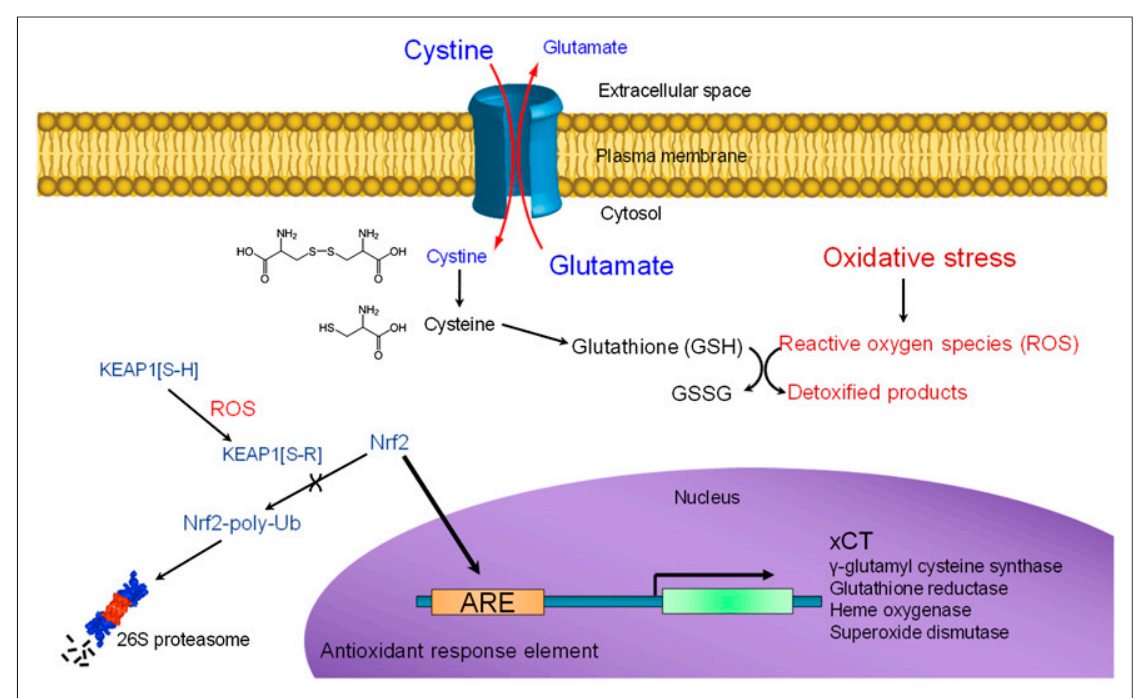

FIGURE 1. Cellular mechanism of $x C T$ expression induced by oxidative stress and promoting increased glutathione synthesis.

oxidative stress distinguishes this biomarker from cell growth and proliferation-based imaging agents. Second, $\mathrm{xCT}$ is accessible at the cell surface and maintains a well-defined (and narrow) natural ligand complement, suggesting that PET tracers can be developed with much better selectivity for this class of transporter. Most amino acid-based PET agents use transport systems ASC or L, which transport 14 of the 20 standard amino acids (5), and many of these amino acids are also substrates for several other molecular transport systems. Of the standard amino acids, only L-glutamate (L-Glu) and L-cystine are substrates for system $\mathrm{x}_{\mathrm{c}}{ }^{-}$, and far fewer additional transport systems use either of these substrates (9), most notably L-Glu as a substrate for the excitatory amino acid transporter of system $\mathrm{X}_{\mathrm{AG}}^{-}(10,11)$. Finally, use of an accumulatory transport mechanism could also serve to improve PET signal contrast through enhanced tracer uptake, compared with saturable binding of an agent to a cell surface protein.

Two groups have reported radiolabeled L-Glu derivatives ${ }^{18} \mathrm{~F}$ (4R)fluoro-L-glutamate ( $\left.{ }^{18} \mathrm{~F}-\mathrm{FGLU}\right)$ and $(4 S)-{ }^{18} \mathrm{~F}$-fluoropropylL-glutamate ( $\left.{ }^{18} \mathrm{~F}-\mathrm{FSPG}\right)$ as PET agent substrates of the cystine/ glutamate transporter for cancer imaging $(3,14-16)$. Here, we report evaluation of a series of anionic amino acids of varying carbon chain lengths to identify the best inhibitor of system $\mathrm{x}_{\mathrm{c}}^{-}$, synthesis of the novel radiofluorinated derivative ${ }^{18} \mathrm{~F}-5$-fluoro-L-aminosuberic acid $\left({ }^{18} \mathrm{~F}-\mathrm{FASu}\right)$, and preclinical evaluation in tumor xenografts. Our efforts to develop a PET imaging substrate of system $\mathrm{x}_{\mathrm{c}}{ }^{-}$focused on amino acid derivatives that show molecular similarities to the natural uptake substrate, L-cystine. We reasoned that the longer carbon backbone of L-aminosuberic acid (L-ASu) was more cystine-like and may be a better transporter substrate because L-cystine was reportedly more potent toward system $\mathrm{x}_{\mathrm{c}}^{-}$than $\mathrm{L}-\mathrm{Glu}(9)$. In addition, cystine-like derivatives may be less likely to participate as substrates for other glutamate transporters or bind to glutamate receptors (17), potentially resulting in better specificity of ${ }^{18} \mathrm{~F}-\mathrm{FASu}$ in peripheral tissues and the brain (18). The cystine/glutamate transporter is often active in oncology $(9,10)$; using this transporter to image a cellular response to oxidative stress may provide functional information useful for clinical cancer care, such as detection, staging, patient stratification, monitoring of response to therapy, and development of new therapies.

\section{MATERIALS AND METHODS}

L-aspartic acid (L-Asp), D-aspartic acid (DAsp), L-Glu, L-leucine (L-Leu), L-serine (L-Ser), suberate, sulfasalazine (SSZ), 2-aminobicyclo(2,2,1)-heptane-2-carboxylic acid (BCH), and diethylmaleate were obtained from Sigma. L-aminoadipic acid, DL-aminopimelic acid, and L-aminosuberic acid (L-ASu) were obtained from Bachem. ${ }^{3} \mathrm{H}$-L-glutmate $\left({ }^{3} \mathrm{H}-\mathrm{L}-\mathrm{Glu}\right)$ and ${ }^{3} \mathrm{H}-\mathrm{L}-$ Leucine ( $\left.{ }^{3} \mathrm{H}-\mathrm{L}-\mathrm{Leu}\right)$ were purchased from American Radiolabeled Chemicals. L-aminoazelaic (L-AAz), L-aminosebacic acid, and L-amino 4,5- ${ }^{3} \mathrm{H}$-suberic acid $\left({ }^{3} \mathrm{H}-\mathrm{L}-\mathrm{ASu}\right)$ were synthesized as described in the supplemental data (supplemental materials are available at http:// jnm.snmjournals.org).

\section{Radiosynthesis of ${ }^{18} \mathrm{~F}-\mathrm{FASu}$}

The synthesis of ${ }^{18} \mathrm{~F}-\mathrm{FASu}$ was independently performed at both GE Global Research and TRIUMF, with efforts at GE Global Research focusing on a radiopharmaceutical preparation method involving high-performance liquid chromatography (HPLC). TRIUMF, along with the BC Cancer Agency, focused on a SepPak (Waters)-based purification method, avoiding the use of HPLC altogether. Detailed descriptions of each group's experimental protocols are provided in the supplemental data. Briefly, ${ }^{18} \mathrm{~F}-\mathrm{FASu}$ was prepared from the tosylate precursor using a 2-step anhydrous ${ }^{18} \mathrm{~F}^{-}$nucleophilic displacement strategy as shown in Figure 2.

\section{Cell Culture Experiments}

The human ovarian carcinoma cell line SKOV-3 and murine lymphoma cell line EL4 were obtained from the American Type Tissue Collection and cultured according to vendor recommendations. Cells were maintained in T-75 culture flasks in a humidified incubator at $37^{\circ} \mathrm{C}$ and $5 \% \mathrm{CO}_{2}$ and routinely passaged at confluence. Tumorigenic cell lines were chosen for in vitro and in vivo studies. EL4 cells were chosen to provide large rapidly growing tumors with potential for assessment in immunocompetent animals (for future studies). SKOV-3 cells were chosen to provide slower-growing tumors with more control over tumor size and relevance to human disease.

SKOV-3 cells were subcultured into 12- or 96-well culture-treated plates and grown to confluence. Cells were incubated with $100 \mu \mathrm{M}$ diethylmaleate $24 \mathrm{~h}$ before the uptake assay. Cells were washed with a 4-(2-hydroxyethyl)-1-piperazineethanesulfonic acid-buffered Hanks Balanced Salt solution (HBS). ${ }^{3} \mathrm{H}-\mathrm{L}-\mathrm{Glu},{ }^{3} \mathrm{H}-\mathrm{L}-\mathrm{ASu},{ }^{3} \mathrm{H}-\mathrm{L}-\mathrm{L} e u$, or ${ }^{18} \mathrm{~F}-$ FASu was added in the absence or presence of a $1 \mathrm{mM}$ concentration of test compound. For 12 -well plate assays, $0.74 \mathrm{kBq}(20 \mathrm{nCi})$ per well was delivered in a $500-\mu \mathrm{L}$ volume (or $0.037 \mathrm{MBq}[1 \mu \mathrm{Ci}$ ] per well for $\left.{ }^{18} \mathrm{~F}-\mathrm{FASu}\right)$. For 96 -well plate assays, $7.4 \mathrm{kBq}(200 \mathrm{nCi})$ per well were delivered in a $50-\mu \mathrm{L}$ volume. Cells were washed 3 times after the uptake incubation period with HBS. For 96-well plate assays, the last wash was aspirated, $200 \mu \mathrm{L}$ of Microscint 20 (Perkin Elmer) were added to each well, and the plate was analyzed with a TopCount microplate scintillation counter (PerkinElmer). For 12-well plate assays, cells were solubilized by the addition of $1 \mathrm{~mL}$ of $1 \mathrm{M} \mathrm{NaOH}$. For uptake in EL4 cells, equal numbers of diethylmaleate-treated cells were aliquoted into microcentrifuge tubes and washed 2 times with HBS by centrifugation. Cell pellets were resuspended in HBS containing ${ }^{18} \mathrm{~F}-\mathrm{FASu}$ in the absence or presence of inhibitor compounds, incubated while rocking at room temperature for $30 \mathrm{~min}$. Cells were washed 2 times with fresh HBS, and cell pellets were resuspended in $500 \mu \mathrm{L}$ of $1 \mathrm{M} \mathrm{NaOH}$. Solubilized samples with tritium were trans- 


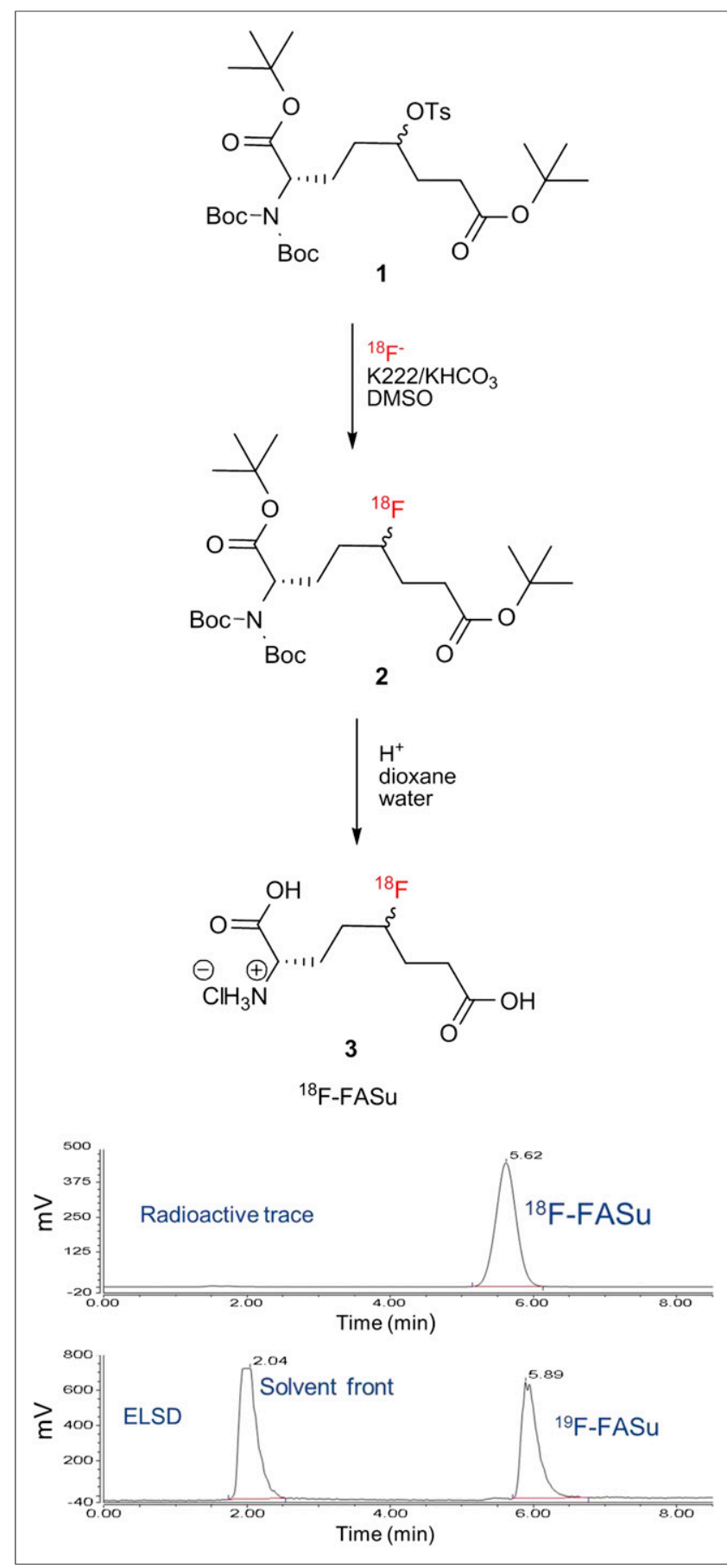

FIGURE 2. 2-step radiosynthesis and identification of ${ }^{18} \mathrm{~F}-\mathrm{FASU}$. HPLC of final product with $y$ detector demonstrates more than $98 \%$ radiochemical purity. HPLC of ${ }^{19} \mathrm{~F}-\mathrm{FASu}$ standard with evaporative light scattering detector (ELSD) shows that differences in retention time of peaks matches $0.27-\mathrm{min}$ (16-s) delay between the 2 detectors.

ferred to a vial with $12 \mathrm{~mL}$ of scintillation cocktail and analyzed with a Tri-Carb scintillation counter (Perkin Elmer). For ${ }^{18}$ F-FASu assays, solubilized cells were added to vials and analyzed using a Wizard $\gamma$ counter (Perkin Elmer).

\section{Small-Animal PET and Biodistribution Studies}

CD-1 nude mice were purchased from Charles River Laboratories, and Rag2-M mice were bred in-house at the BC Cancer Agency.
Animals were housed under sterile conditions with food and water ad libitum and a 12-h light cycle. Mice were injected subcutaneously with $1 \times 10^{7}$ EL4 or SKOV-3 cells in phosphate-buffered saline or culture medium while under $2 \%$ isoflurane anesthesia, and tumors were allowed to grow for approximately $5-10$ or $21 \mathrm{~d}$, respectively. All animal studies were performed in accordance with federal and Institutional Animal Care and Use Committee guidelines using approved protocols.

For biodistribution studies, mice bearing EL4 tumor xenografts were injected via the tail vein with between 0.07 and $0.59 \mathrm{MBq}(2-16$ $\mu \mathrm{Ci}$ ) of ${ }^{18} \mathrm{~F}-\mathrm{FASu}$. Direct comparison of ${ }^{18} \mathrm{~F}-\mathrm{FASu}$ and ${ }^{18} \mathrm{~F}-\mathrm{FDG}$ involved a cohort of 10 nude mice bearing SKOV-3 tumors randomly separated into 2 groups of 5; each group was injected with approximately $0.44 \mathrm{MBq}(12 \mu \mathrm{Ci})$ of either ${ }^{18} \mathrm{~F}-\mathrm{FASu}$ or ${ }^{18} \mathrm{~F}-\mathrm{FDG}$. Mice were euthanized by $\mathrm{CO}_{2}$ asphyxiation at the postinjection time points indicated, and then blood was collected by cardiac puncture and organs were excised, weighed, and counted on a $\gamma$ counter. All urine was collected on filter paper and counted with the bladder. The unused tissues and remaining carcass were collected and counted. The percentage injected dose per gram (\%ID/g) was calculated using the sum of the counts from all tissues, urine, and carcass as the injected dose value.

For PET imaging studies, CD-1 nude mice bearing SKOV-3 tumors were injected with $8.5-11.1 \mathrm{MBq}(230-300 \mu \mathrm{Ci})$ of ${ }^{18} \mathrm{~F}-\mathrm{FASu}$ via the tail vein. PET imaging data were acquired with an eXplore VISTA preclinical PET scanner (GE Healthcare) under 2\% isoflurane anesthesia. Static PET data conducted at $1 \mathrm{~h}( \pm 5 \mathrm{~min})$ after injection were acquired over $10 \mathrm{~min}$ (55-65 min after injection) using 2 bed positions. Mice were then immediately euthanized while under anesthesia by cervical dislocation, and an ${ }^{18} \mathrm{~F}$ biodistribution evaluation was performed as described above. Images were reconstructed, and region-ofinterest analysis was performed on the tumor. The injected dose for imaging studies was determined with a dose calibrator (Capintec). \% $\mathrm{ID} / \mathrm{g}$ and standardized uptake value were calculated using a scaling factor determined by analysis of an equivalent acquisition of a dose-calibrated ${ }^{18} \mathrm{~F}-\mathrm{FASu}$ standard.

Alternatively, Rag2-M mice bearing EL4 tumors were anesthetized ( $2 \%$ isoflurane), a $27.5-\mathrm{Ga}$ catheter intravenous line containing saline was placed into the tail, and the rodent was positioned on the scanner imaging bed with integrated heating pad (Inveon; Siemens). Each PET scan was initiated using between 4.5 and $16.4 \mathrm{MBq}(122-444 \mu \mathrm{Ci})$ of ${ }^{18} \mathrm{~F}-\mathrm{FASu}$ in no more than $125 \mu \mathrm{L}$ of saline administered via the intravenous line. PET data were collected in list-mode for up to $2 \mathrm{~h}$ after injection of the tracer. Scan data were then reconstructed with correction from CT-based attenuation, and regions of interest were placed on the tumor and organs of interest to evaluate the time-activity curves for ${ }^{18} \mathrm{~F}-\mathrm{FASu}$ in the tissues of interest.

\section{RESULTS}

\section{In Vitro Cell Uptake Studies}

The inhibition of ${ }^{3} \mathrm{H}-\mathrm{L}-\mathrm{Glu}$ uptake in SKOV-3 cells determined for anionic amino acids ranging from 4 carbons $\left(\mathrm{C}_{4}\right)$ to 10 carbons $\left(\mathrm{C}_{10}\right)$ is shown in Figure 3A. L-Leu and suberate were also examined as negative control compounds. A specific system $\mathrm{x}_{\mathrm{c}}{ }^{-}$nonsubstrate inhibitor, sulfasalazine, was used as a positive control. The results show that the 5-carbon L-Glu inhibits ${ }^{3} \mathrm{H}-\mathrm{L}-\mathrm{Glu}$ uptake via the $\mathrm{x}_{\mathrm{c}}{ }^{-}$transporter by $83 \%$. As the carbon chain is extended to $6-$, 7-, or 10 -carbon atoms in length, the inhibition of ${ }^{3} \mathrm{H}-\mathrm{L}-\mathrm{Glu}$ uptake is reduced to between $40 \%$ and $70 \%$. However, the 8-carbon compound $\mathrm{L}-\mathrm{ASu}$ and the 9-carbon derivative $\mathrm{L}-\mathrm{AAz}$ demonstrate inhibition of ${ }^{3} \mathrm{H}-\mathrm{L}-\mathrm{Glu}$ uptake similar to $\mathrm{L}-\mathrm{Glu}$ at $85 \%$ and $79 \%$, respectively. The best inhibitors appear to have a distance between the 2 terminal carboxyl groups (in a fully extended conformation) 

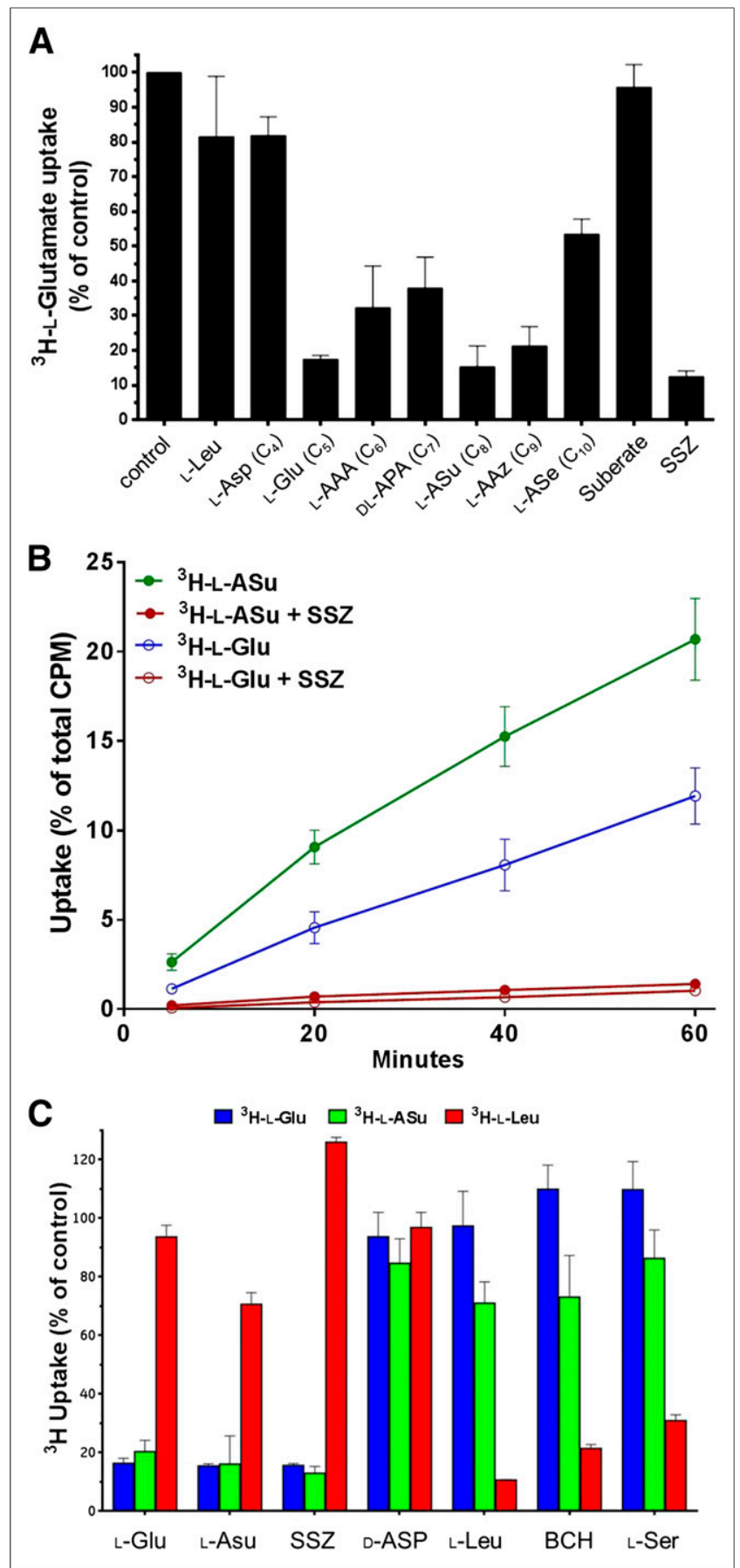

FIGURE 3. In vitro system $x_{c}^{-}$inhibition, uptake, and specificity studies in diethylmaleate-treated SKOV-3 cells. (A) Competitive inhibition of test agents on ${ }^{3} \mathrm{H}-\mathrm{L}-\mathrm{Glu}$ uptake during 30 -min incubation. L-Asp, L-Glu, L-aminoadipic acid, DL-aminopimelic acid, L-ASu, L-AAz, and L-aminosebacic acid are all anionic amino acids from 4 to 10 carbons $\left(\mathrm{C}_{4}-\mathrm{C}_{10}\right)$ in length, respectively. Values are normalized to uptake of ${ }^{3} \mathrm{H}-\mathrm{L}-\mathrm{Glu}$ in phosphate-buffered saline alone (mean $\pm \mathrm{SD}, n=3$ ). (B) Comparison of direct cell uptake of ${ }^{3} \mathrm{H}-\mathrm{L}-\mathrm{ASu}$ and ${ }^{3} \mathrm{H}-\mathrm{L}-\mathrm{Glu}$. ${ }^{3} \mathrm{H}-\mathrm{L}-\mathrm{ASu}$ and ${ }^{3} \mathrm{H}-\mathrm{L}-\mathrm{Glu}$ were matched for specific activity and radiation dose per sample. Uptake values are expressed as percentage of total activity used per well (mean \pm $\mathrm{SD}, n=3$ ). (C) Comparison of ${ }^{3} \mathrm{H}-\mathrm{L}-\mathrm{Glu},{ }^{3} \mathrm{H}-\mathrm{L}-\mathrm{ASu}$, and ${ }^{3} \mathrm{H}-\mathrm{L}-\mathrm{Leu}$ uptake in presence of selected amino acid transporter inhibitors for $30 \mathrm{~min} .{ }^{3} \mathrm{H}-\mathrm{L}-$ Glu, ${ }^{3} \mathrm{H}$-L-ASu, and ${ }^{3} \mathrm{H}$-L-Leu were matched for specific activity and radiation dose per sample. Values are normalized to uptake of each agent in phosphate-buffered saline alone (mean $\pm \mathrm{SD}, n=3$ ). SSZ = sulfasalazine. that best approximates the distances in the natural substrates L-Glu (5.0 $\AA, \mathrm{C}_{5}$ ) and L-cystine (9.8 $\AA$, between $\mathrm{C}_{8}$ and $\mathrm{C}_{9}$ ). Negative controls suberate and L-Leu, as well as the 4-carbon L-Asp, showed less than $20 \%$ inhibition of ${ }^{3} \mathrm{H}-\mathrm{L}-\mathrm{Glu}$ uptake.

A comparison of direct uptake of ${ }^{3} \mathrm{H}-\mathrm{L}-\mathrm{ASu}$ and ${ }^{3} \mathrm{H}-\mathrm{L}-\mathrm{Glu}$ in SKOV-3 cells is shown in Figure 3B. ${ }^{3} \mathrm{H}-\mathrm{L}-\mathrm{ASu}$ uptake was 2.3, 2.0, 1.9, and 1.7 times more than the uptake of ${ }^{3} \mathrm{H}-\mathrm{L}-\mathrm{Glu}$ at 5,20 , 40, and $60 \mathrm{~min}$, respectively. These results suggest that while competitive inhibition results were similar, L-ASu appears to be a more efficient transporter substrate, resulting in better in vitro uptake. Uptake of ${ }^{3} \mathrm{H}-\mathrm{L}-\mathrm{ASu}$ and ${ }^{3} \mathrm{H}-\mathrm{L}-\mathrm{Glu}$ was inhibited $92.6 \%$ and $92.1 \%$, respectively, with $500 \mu \mathrm{M}$ sulfasalazine, suggesting that most uptake of these agents can be attributed to the $\mathrm{x}_{\mathrm{c}}{ }^{-}$transporter.

To evaluate specificity of L-ASu for the system $\mathrm{x}_{\mathrm{c}}{ }^{-}$transporter, we measured the uptake of ${ }^{3} \mathrm{H}-\mathrm{L}-\mathrm{Glu},{ }^{3} \mathrm{H}-\mathrm{L}-\mathrm{ASu}$, and ${ }^{3} \mathrm{H}-\mathrm{L}-\mathrm{Leu}$ in the absence and presence of inhibitors (Fig. 3C). Inhibitors used included the system $\mathrm{x}_{\mathrm{c}}{ }^{-}$inhibitor sulfasalazine; the excitatory amino acid transporter inhibitor D-Asp; transport systems L, B ${ }^{0}$, and $\mathrm{B}^{0+}$ inhibitor L-Leu; transport system $\mathrm{L}$ inhibitor $\mathrm{BCH}$; and systems $\mathrm{A}, \mathrm{ASC}, \mathrm{B}^{0}$, and $\mathrm{B}^{0+}$ inhibitor $\mathrm{L}-\mathrm{Ser}$. Results demonstrate less than $20 \%$ uptake relative to controls for ${ }^{3} \mathrm{H}-\mathrm{L}-\mathrm{Glu}$ and ${ }^{3} \mathrm{H}-\mathrm{L}-$ $\mathrm{ASu}$ in the presence of $\mathrm{L}-\mathrm{Glu}, \mathrm{L}-\mathrm{ASu}$, and sulfasalazine, with little, if any, effect on uptake in the presence of $\mathrm{L}-\mathrm{Leu}, \mathrm{BCH}$, and L-Ser. An inverse relationship was noted for ${ }^{3} \mathrm{H}-\mathrm{L}-\mathrm{Leu}$, demonstrating more than $80 \%$ uptake in the presence of L-Glu, L-Asu, and sulfasalazine and pronounced inhibition with the latter 3 inhibitors. DAsp had little inhibitory effect on all tracers.

\section{Radiosynthesis and Uptake of ${ }^{18} \mathrm{~F}-\mathrm{FASu}$}

Both GE Global Research and TRIUMF used a 2-step nucleophilic displacement strategy for the synthesis of ${ }^{18}$ F-FASu (Fig. 2) but proceeded to tracer formulation with and without HPLC purification, respectively. Decay-corrected yields were between $5 \%$ and $15 \%$, with more than $98 \%$ radiochemical purity as determined by peak integration of the corresponding analytical HPLC traces, and were dependant on the experimental protocol. The radiochemical purity of the final product after isolation was more than $98 \%$, regardless of the synthetic method used.

The uptake of ${ }^{3} \mathrm{H}-\mathrm{L}-\mathrm{ASu}$ and ${ }^{18} \mathrm{~F}-\mathrm{FASu}$ were both inhibited in EL4 cells by L-ASu and L-Glu (Fig. 4A), suggesting that ${ }^{18} \mathrm{~F}-\mathrm{FASu}$ is also a substrate for the system $\mathrm{x}_{\mathrm{c}}{ }^{-}$transporter. ${ }^{18} \mathrm{~F}-\mathrm{FASu}$ was assayed for cell uptake in cultured SKOV-3 cells (Fig. 4B) and showed nonsaturable uptake over $1 \mathrm{~h}$, which is potently inhibited to between $7 \%$ and $16 \%$ of control by sulfasalazine, consistent with uptake via system $\mathrm{x}_{\mathrm{c}}{ }^{-}$. Because system $\mathrm{x}_{\mathrm{c}}{ }^{-}$activity and ${ }^{18} \mathrm{~F}-$ FASu uptake were observed in these in vitro models, we decided to evaluate uptake and imaging in EL4 and SKOV-3 subcutaneous xenograft tumors in vivo.

\section{${ }^{18} \mathrm{~F}-\mathrm{FASu}$ In Vivo Biodistribution and Imaging Studies}

In vivo biodistribution studies were first performed in CD-1 nude mice bearing subcutaneous EL4 xenograft tumors. The clearance of ${ }^{18} \mathrm{~F}$-FASu in mice is shown in Figure 5A. Renal clearance predominates because most activity is quickly partitioned to the kidney, bladder, and urine. Tracer continued to accumulate in the bladder and urine and to clear from blood, kidneys, liver, and spleen over the course of $4 \mathrm{~h}$. Figure 5B shows that EL4 tumor uptake is significant and remains fairly constant up to $2 \mathrm{~h}$ after injection. Evaluation of ${ }^{18} \mathrm{~F}-\mathrm{FASu}$ tissue distribution at $1 \mathrm{~h}$ after tail vein injection is shown in Table 1, with tumor-to-blood 


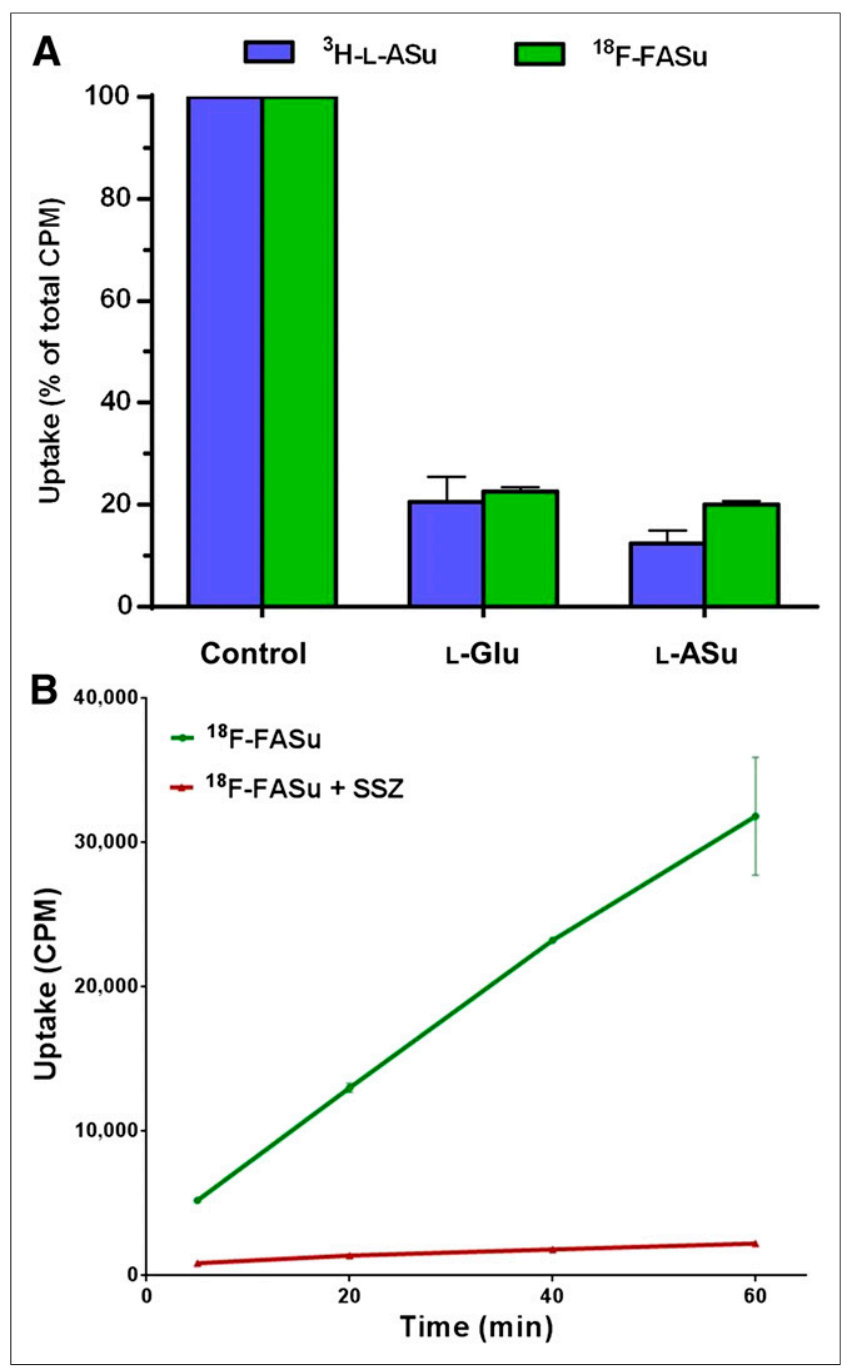

FIGURE 4. Uptake of HPLC-purified ${ }^{18} \mathrm{~F}-\mathrm{FASu}$ in EL4 and SKOV-3 cells in vitro. (A) EL4 cells were evaluated for uptake of ${ }^{3} \mathrm{H}-\mathrm{L}-\mathrm{ASu}$ and ${ }^{18} \mathrm{~F}-\mathrm{FASu}$ in absence or presence of $1 \mathrm{mM} \mathrm{L}$-Glu or L-ASu for $30 \mathrm{~min}$. Uptake and inhibition profiles were similar for both radiolabeled compounds. Values are normalized to uptake of each agent in phosphatebuffered-saline-alone control (mean $\pm \mathrm{SD}, n=4$ ). (B) ${ }^{18} \mathrm{~F}$-FASu uptake in SKOV-3 cells in absence and presence of $0.5 \mathrm{mM}$ sulfasalazine was evaluated with 5-, 20-, 40-, and 60-min incubations. Uptake values are raw CPM values per sample (mean $\pm \mathrm{SD}, n=3$ ). SSZ = sulfasalazine.

ratios of approximately 12 and tumor-to-muscle ratios of approximately $28 .{ }^{18} \mathrm{~F}-\mathrm{FASu}$ also demonstrated prominent retention in the pancreas and significant retention in the spleen.

We conducted a side-by-side comparison of ${ }^{18} \mathrm{~F}-\mathrm{FASu}$ and ${ }^{18} \mathrm{~F}$ FDG in CD-1 nude mice bearing SKOV-3 tumors at $1 \mathrm{~h}$ after injection (Table 1); we chose the SKOV-3 cells for this study because their slow growth allowed for more control over tumor size. ${ }^{18} \mathrm{~F}-\mathrm{FASu}$ tumor uptake at $1 \mathrm{~h}$ after injection reached 8.1 $\% \mathrm{ID} / \mathrm{g}$, with tumor-to-blood and tumor-to-muscle ratios of approximately 12 and approximately 30, respectively. As expected, ${ }^{18} \mathrm{~F}-\mathrm{FASu}$ also showed pronounced uptake in the pancreas and spleen. ${ }^{18} \mathrm{~F}-\mathrm{FDG}$ tissue distribution is also shown in Table 1 . Compared with ${ }^{18} \mathrm{~F}$-FDG, ${ }^{18} \mathrm{~F}$-FASu showed a 5.2-fold-greater tumor uptake and a 4.6-fold-greater tumor-to-blood ratio. ${ }^{18} \mathrm{~F}$-FASu also demonstrated much lower background in muscle, heart, and brain.
CD-1 nude mice bearing SKOV-3 tumor xenografts were injected with ${ }^{18} \mathrm{~F}$-FASu by tail vein, and PET imaging was conducted $1 \mathrm{~h}$ after injection (Fig. 6). Tumor uptake obtained by necropsy biodistribution evaluation of the mouse immediately after imaging, $8.4 \% \mathrm{ID} / \mathrm{g}$, correlated well with the mean tumor uptake analysis from the PET image, $8.6 \%$ ID per cubic centimeter $\left(\% \mathrm{ID} / \mathrm{cm}^{3}\right)$. Maximum pixel intensity in the tumor was 16.7 $\% \mathrm{ID} / \mathrm{cm}^{3}$. The mean standardized uptake values of the tumor were 2.5 and 4.9, respectively. Imaging results were consistent with SKOV-3 biodistribution data shown in Table 1.

Dynamic PET images of EL4 tumors in Rag2-M mice (Fig. 7A) revealed a rapid and high initial tumor uptake exceeding $6 \% \mathrm{ID} / \mathrm{cm}^{3}$ by $40 \mathrm{~min}$ after injection, staying close to this level for the 2-h duration of the scan (Fig. 7B). A high tumor-to-muscle ratio of approximately 13 at $120 \mathrm{~min}$ after injection was also indicative of a low overall background uptake of the tracer. Uptake in the kidneys

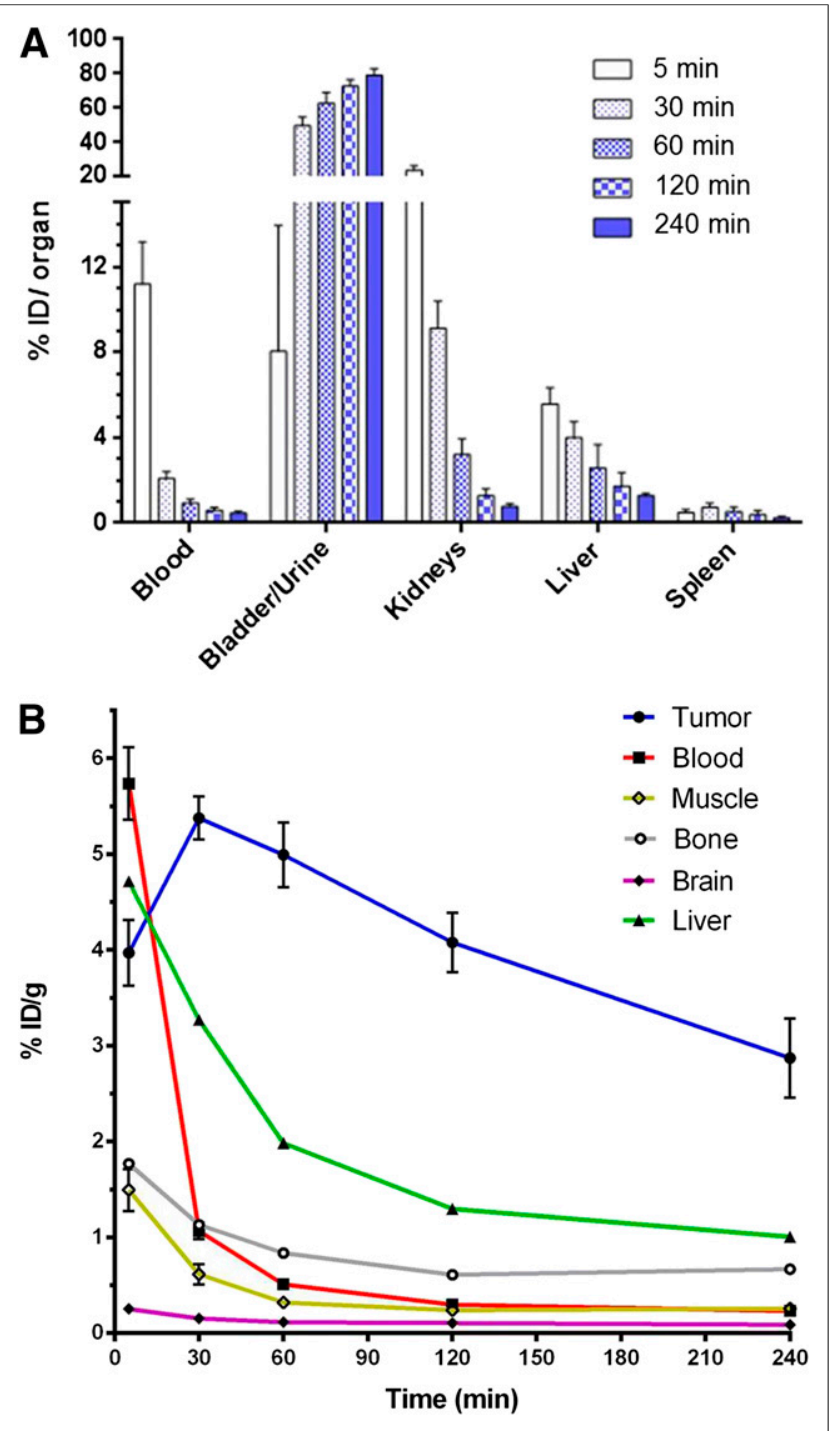

FIGURE 5. In vivo biodistribution in CD-1 nude mice bearing EL4 xenograft tumors with HPLC-purified ${ }^{18} \mathrm{~F}$-FASu. (A) ${ }^{18} \mathrm{~F}$-FASu retention in clearance organs at $5,30,60,120$, and 240 min after injection are shown in \%ID/organ. (B) ${ }^{18} \mathrm{~F}-\mathrm{FASu}$ retention in tumor, blood, muscle, bone, brain, and liver. Data are \%ID/g (mean $\pm \mathrm{SD}, n \geq 4$ ). 


\begin{tabular}{|c|c|c|c|}
\hline \multirow[b]{2}{*}{ Organ or tissue } & \multirow[b]{2}{*}{ EL4 tumors, ${ }^{18} \mathrm{~F}-\mathrm{FASu}$} & \multicolumn{2}{|c|}{ SKOV-3 tumors } \\
\hline & & ${ }^{18} \mathrm{~F}-\mathrm{FDG}$ & ${ }^{18} \mathrm{~F}-\mathrm{FASu}$ \\
\hline Blood & $0.49 \pm 0.12$ & $0.58 \pm 0.30$ & $0.72 \pm 0.30$ \\
\hline Tumor & $5.81 \pm 1.26$ & $1.55 \pm 0.96$ & $8.08 \pm 2.03$ \\
\hline Muscle & $0.25 \pm 0.16$ & $4.92 \pm 2.26$ & $0.35 \pm 0.17$ \\
\hline Liver & $1.24 \pm 0.18$ & $0.74 \pm 0.15$ & $0.86 \pm 0.08$ \\
\hline Kidney & $10.11 \pm 2.58$ & $1.04 \pm 0.16$ & $15.36 \pm 5.63$ \\
\hline Spleen & $4.98 \pm 1.28$ & $1.73 \pm 0.59$ & $6.74 \pm 1.02$ \\
\hline Heart & $0.33 \pm 0.09$ & $54.11 \pm 29.00$ & $0.32 \pm 0.07$ \\
\hline Lungs & $2.00 \pm 0.38$ & $3.61 \pm 1.68$ & $1.95 \pm 0.97$ \\
\hline Brain & $0.11 \pm 0.03$ & $7.76 \pm 2.77$ & $0.09 \pm 0.02$ \\
\hline Bone & $0.85 \pm 0.26$ & $3.58 \pm 1.74$ & $0.85 \pm 0.53$ \\
\hline Pancreas & $23.34 \pm 5.73$ & $1.49 \pm 0.54$ & $21.19 \pm 6.61$ \\
\hline Fat & $0.29 \pm 0.22$ & $0.59 \pm 0.36$ & $0.62 \pm 0.67$ \\
\hline Tumor-to-blood & $12.01 \pm 1.58$ & $2.61 \pm 0.27$ & $12.08 \pm 0.4 .39$ \\
\hline Tumor-to-muscle & $28.16 \pm 10.39$ & $0.33 \pm 0.13$ & $29.59 \pm 19.44$ \\
\hline Tumor size & $1,140 \pm 296$ & $72.60 \pm 37.65$ & $71.60 \pm 39.09$ \\
\hline
\end{tabular}

and bladder was consistent with renal clearance. Liver retention was low relative to tumor, and the bone signal cleared to less than 1 $\% \mathrm{ID} / \mathrm{cm}^{3}$, indicating that defluorination is not a prevalent metabolic pathway for ${ }^{18} \mathrm{~F}-\mathrm{FASu}$.

\section{DISCUSSION}

${ }^{18}$ F-FDG and many amino acid analog PET tracers enable detection and monitoring of tumors based on cellular metabolic changes required for sustaining cell growth and proliferation. Amino acids are needed by highly proliferative cells for anabolic protein and nucleotide synthesis and also contribute to energy metabolism by providing a carbon source for the tricarboxylic acid cycle (19). The use of amino acid analogs as PET tracers is useful, not because tumor cells increase their metabolism but rather because they enhance amino acid transport mechanisms to feed that metabolism. Here we use an L-cystine analog to target the narrow substrate profile of the cystine/glutamate transporter as a reporter of oxidative stress.

Two glutamate analogs have been reported as system $\mathrm{x}_{\mathrm{c}}{ }^{-}$substrate PET agents, ${ }^{18}$ F-FGLU and ${ }^{18}$ F-FSPG $(3,14)$. Our development strategy differed from previous reports in that we focused on a compound with similarity to the preferred uptake substrate L-cystine (9). Our lead compound, L-ASu, has an 8-atom backbone mirroring cystine while lacking a problematic disulfide bond and 1 amine to better maintain the anionic nature vital to system $\mathrm{x}_{\mathrm{c}}{ }^{-}$ substrates at physiologic $\mathrm{pH}$. Indeed, we demonstrated that ${ }^{3} \mathrm{H}-\mathrm{L}-$ ASu was taken up more efficiently than ${ }^{3} \mathrm{H}-\mathrm{L}-\mathrm{Glu}$ in our in vitro studies with SKOV-3 cells. Longer-chain anionic amino acids, such as L-ASu, have been shown to have drastically reduced affinity for metabotropic glutamate receptors $(17,20)$; therefore, we proposed that cystine-like compounds may have a benefit of specificity over glutamate-like compounds, which are more likely to bind various glutamate receptors or use transport system $\mathrm{X}^{-}{ }_{\mathrm{AG}}$. Koglin et al. reported ${ }^{18} \mathrm{~F}-\mathrm{FSPG}$ uptake in SKOV-3 tumors at approximately $3 \% \mathrm{ID} / \mathrm{g}$, whereas we demonstrated ${ }^{18} \mathrm{~F}$-FASu SKOV-3 tumor uptake of approximately $8 \% \mathrm{ID} / \mathrm{g}$ at the same time after injection. In addition, reports of preclinical and human evaluation of ${ }^{18} \mathrm{~F}$-FSPG have generally demonstrated tumor uptake similar to or less than ${ }^{18} \mathrm{~F}$-FDG (14-16). We demonstrated here that ${ }^{18} \mathrm{~F}$-FASu resulted in a 5 -fold enhanced uptake over ${ }^{18} \mathrm{~F}$ FDG in SKOV-3 tumor xenografts. Further studies comparing $\mathrm{x}_{\mathrm{c}}{ }^{-}$ selectivity; glutamate receptor binding; in vitro system $\mathrm{x}_{\mathrm{c}}{ }^{-}$uptake; in vivo biodistribution; and imaging with ${ }^{18} \mathrm{~F}-\mathrm{FASu},{ }^{18} \mathrm{~F}-\mathrm{FGLU}$, and ${ }^{18} \mathrm{~F}-\mathrm{FSPG}$ will help evaluate differences in tracer performance. Additional comparisons with ${ }^{18} \mathrm{~F}$-FDG may reveal specific indications in which ${ }^{18} \mathrm{~F}$-FASu would be superior to or useful in addition to ${ }^{18} \mathrm{~F}-\mathrm{FDG}$.

Activation of the gene (SLC7A11) encoding the $\mathrm{xCT}$ subunit of the $\mathrm{X}_{\mathrm{C}}{ }^{-}$transport system has been reported in several cancers and cancer cell lines (10), with several groups exploring the feasibility of using the $\mathrm{xCT}$ transporter as a viable target for cancer therapy $(10,21,22)$ by inducing cysteine starvation. Inhibition of the transporter reportedly restricts the growth of lymphoma $(23,24)$, glioma $(25,26)$, head and neck $(27)$, breast $(22)$, prostate (28), lung (29), and pancreatic $(21,30)$ cancer cells both in culture and in in vivo xenograft tumors. Increased xCT transporter activity is also associated with resistance of tumors to certain types of chemotherapy, and inhibition of the xCT transporter has been shown to increase the sensitization of cancer cells to the chemotherapeutic drugs cisplatin, doxorubicin, gemcitabine, celastrol, and etoposide $(27,31)$. Recently, a role for xCT in tumor metastatic potential has been established (32). xCT has also been linked to an undifferentiated stem-like tumor cell phenotype through its interaction with CD44 (27,33). A limited clinical study showed some success with sulfasalazine in combination with melphalan in ovarian cancer (34), whereas more recently a clinical trial has started in Japan for treatment of advanced gastric cancer with sulfasalazine (Unique Trial Number UMIN000010254). Using this transporter to image a cellular response to oxidative stress may provide functional information useful for clinical cancer care, such as detection, staging, patient stratification, and monitoring of response to therapy. If system $\mathrm{x}_{\mathrm{c}}{ }^{-}$-targeted therapies such as sulfasalazine prove efficacious in 


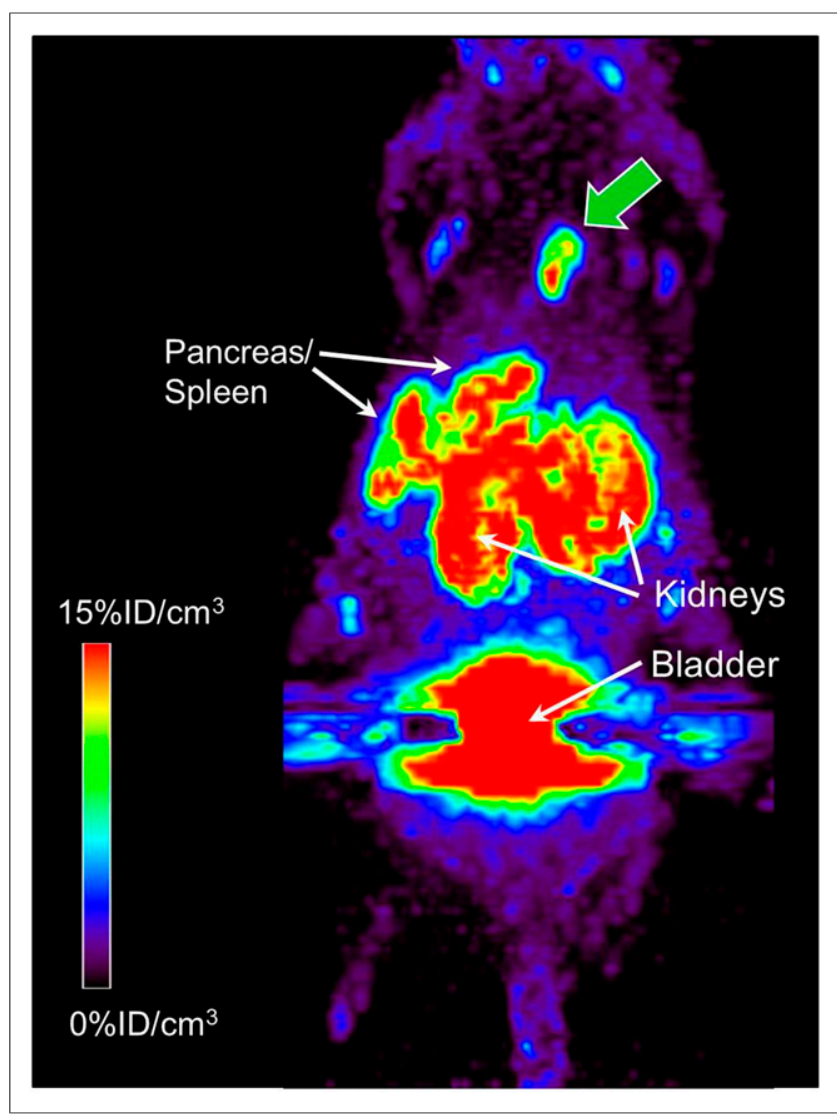

FIGURE 6. ${ }^{18} \mathrm{~F}-\mathrm{FASU} \mathrm{PET}$ imaging in CD-1 nude mice bearing SKOV-3 xenograft tumors $1 \mathrm{~h}$ after injection. Maximum-intensity-projection image of 1 of 2 SKOV-3 tumor-bearing nude mice imaged in this study; tumor is indicated by green arrow. ${ }^{18} \mathrm{~F}$-FASu was HPLC-purified. On necropsy, it was determined that weight of this tumor was $31 \mathrm{mg}$.

clinical trials, companion diagnostic xCT-targeted PET tracers, such as ${ }^{18} \mathrm{~F}-\mathrm{FASu}$, may allow stratification of patients who will respond to treatment.

Oxidative stress has also been implicated in a wide variety of pathologies other than oncology, including neurodegenerative
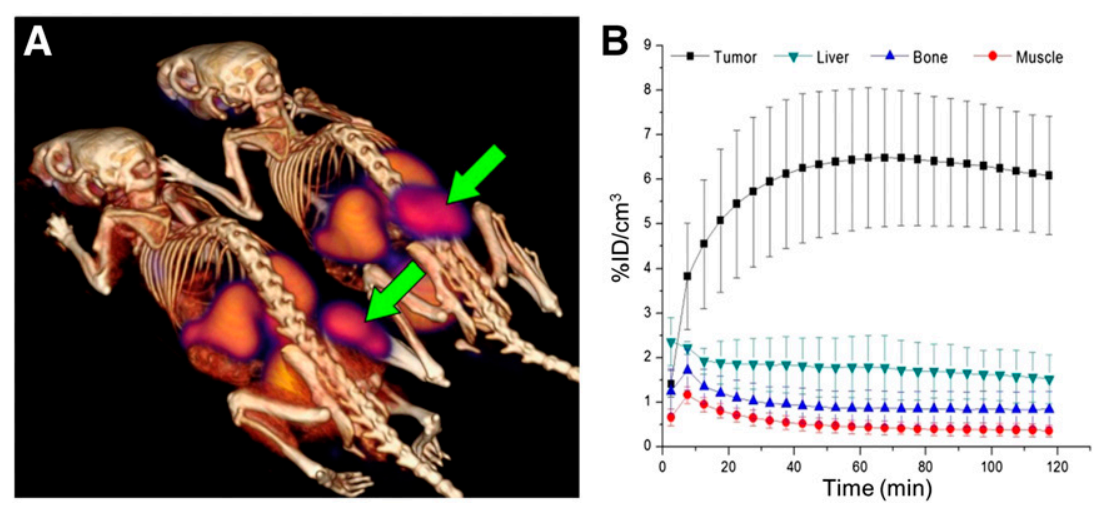

FIGURE 7. In vivo ${ }^{18} \mathrm{~F}-\mathrm{FASu}$ dynamic PET imaging in Rag2 $\mathrm{M}$ mice bearing EL4 xenograft tumor. ${ }^{18}$ F-FASu was SepPak-purified. (A) PET/CT image summed over 110-120 min after injection. Tumors are indicated by arrows. (B) Region-of-interest analysis of ${ }^{18} \mathrm{~F}$-FASu uptake in tumor, liver, bone, and muscle (mean $\pm \mathrm{SD}, n=4$ ). diseases, atherosclerosis, ischemia, organ transplant rejection, autoimmune diseases, and inflammatory conditions. An xCTtargeted imaging agent such as ${ }^{18} \mathrm{~F}-\mathrm{FASu}$ may provide functional information relevant to many pathologic conditions. For example, whereas $\mathrm{x}_{\mathrm{c}}{ }^{-}$transporter activity in the brain will provide an antioxidant defense against oxidative stress, the same mechanism appears to be complicit in neurodegeneration resulting from excitotoxic stimulation of ionotropic glutamate receptors by glutamate effluxed via system $\mathrm{x}_{\mathrm{c}}{ }^{-}(9,35-38) .{ }^{18} \mathrm{~F}-\mathrm{FASu},{ }^{18} \mathrm{~F}-\mathrm{FGLU}$, and ${ }^{18} \mathrm{~F}-$ FSPG are not expected to be permeable to an intact blood-brain barrier, and high basal expression of $\mathrm{xCT}$ is reported in normal brain. Despite this, others have reported uptake of ${ }^{18} \mathrm{~F}-\mathrm{FSPG}$ in human brain tumors (39). However, the mechanism of uptake is not clearly tumor cell-specific, because normal brain tissue uptake might be expected in regions of blood-brain barrier perturbations correlating with tumor growth or other conditions. Future studies in our group will seek to evaluate the feasibility of $\mathrm{xCT}$ in the brain as a potential PET tracer target.

\section{CONCLUSION}

$\mathrm{L}-\mathrm{ASu}$ is taken up into cells with system $\mathrm{x}_{\mathrm{c}}{ }^{-}$activity more readily than the natural substrate $\mathrm{L}-\mathrm{Glu}$. We have developed a novel system $\mathrm{x}_{\mathrm{c}}{ }^{-}$substrate and demonstrated feasibility of PET imaging in SKOV-3 and EL4 tumor xenografts. ${ }^{18}$ F-FASu essentially serves as a reporter for the activation of the ARE promoter, allowing functional PET imaging of a universal cellular response to oxidative stress. The mechanism of ${ }^{18} \mathrm{~F}$-FASu uptake is orthogonal to increased glucose and general amino acid uptake that is common to highly proliferative cells. ${ }^{18} \mathrm{~F}$-FASu may provide more sensitive detection than ${ }^{18} \mathrm{~F}$-FDG for certain tumor types, as was seen in SKOV-3 xenografts. Oxidative stress imaging may also find utility in determining chemotherapy resistance and as a predictor of early response to therapy.

\section{DISCLOSURE}

The costs of publication of this article were defrayed in part by the payment of page charges. Therefore, and solely to indicate this fact, this article is hereby marked "advertisement" in accordance with 18 USC section 1734. Research reported in this publication was supported by the NIBIB and NIH under award number R01EB014250. Jack M. Webster, Bruce F. Johnson, Michael J. Rishel, and Christine A. Morton are employed by General Electric. No other potential conflict of interest relevant to this article was reported.

\section{ACKNOWLEDGMENTS}

We thank Dr. Francois Bénard for guidance, along with May Wong and the staff of the Animal Resource Centre at the BC Cancer Agency, and Andrew Torres at GE for their skillful technical assistance during the imaging and biodistribution studies. We also thank the TRIUMF cyclotron team, in particular Linda Graham, Wade English, and Cornelia Hoehr, for their assistance in the development of the automated synthesis process. 


\section{REFERENCES}

1. Neels OC, Koopmans KP, Jager PL, et al. Manipulation of $\left[{ }^{11} \mathrm{C}\right]-5$-hydroxytryptophan and $6-\left[{ }^{18} \mathrm{~F}\right]$ fluoro-3,4-dihydroxy-L-phenylalanine accumulation in neuroendocrine tumor cells. Cancer Res. 2008;68:7183-7190.

2. Kasper BS, Struffert T, Kasper EM, et al. ${ }^{18}$ Fluoroethyl-L-tyrosine-PET in longterm epilepsy associated glioneuronal tumors. Epilepsia. 2011;52:35-44.

3. Ploessl K, Wang L, Lieberman BP, Qu W, Kung HF. Comparative evaluation of ${ }^{18} \mathrm{~F}$-labeled glutamic acid and glutamine as tumor metabolic imaging agents. J Nucl Med. 2012;53:1616-1624.

4. McConathy J, Yu W, Jarkas N, Seo W, Schuster DM, Goodman MM. Radiohalogenated nonnatural amino acids as PET and SPECT tumor imaging agents. Med Res Rev. 2012;32:868-905.

5. Fuchs BC, Bode BP. Amino acid transporters ASCT2 and LAT1 in cancer: partners in crime? Semin Cancer Biol. 2005;15:254-266.

6. Bannai S, Kitamura E. Transport interaction of L-cystine and L-glutamate in human diploid fibroblasts in culture. J Biol Chem. 1980;255:2372-2376.

7. Okuno S, Sato H, Kuriyama-Matsumura K, et al. Role of cystine transport in intracellular glutathione level and cisplatin resistance in human ovarian cancer cell lines. Br J Cancer. 2003;88:951-956.

8. Valdovinos-Flores C, Gonsebatt ME. The role of amino acid transporters in GSH synthesis in the blood-brain barrier and central nervous system. Neurochem Int. 2012;61:405-414.

9. Lewerenz J, Hewett SJ, Huang Y, et al. The cystine/glutamate antiporter system $\mathrm{x}_{\mathrm{c}}{ }^{-}$in health and disease: from molecular mechanisms to novel therapeutic opportunities. Antioxid Redox Signal. 2013;18:522-555.

10. Lo $\mathrm{M}$, Wang $\mathrm{YZ}$, Gout $\mathrm{PW}$. The $\mathrm{x}_{\mathrm{c}}{ }^{-}$cystine/glutamate antiporter: a potential target for therapy of cancer and other diseases. J Cell Physiol. 2008;215: 593-602.

11. Conrad M, Sato H. The oxidative stress-inducible cystine/glutamate antiporter, system $\mathrm{x}_{\mathrm{c}}$ - cystine supplier and beyond. Amino Acids. 2012;42:231-246.

12. Nguyen T, Nioi P, Pickett CB. The Nrf2-antioxidant response element signaling pathway and its activation by oxidative stress. J Biol Chem. 2009;284: 13291-13295.

13. Sasaki H, Sato H, Kuriyama-Matsumura K, et al. Electrophile response elementmediated induction of the cystine/glutamate exchange transporter gene expression. J Biol Chem. 2002;277:44765-44771.

14. Koglin N, Mueller A, Berndt M, et al. Specific PET imaging of $x_{C}{ }^{-}$transporter activity using a ${ }^{18} \mathrm{~F}$-labeled glutamate derivative reveals a dominant pathway in tumor metabolism. Clin Cancer Res. 2011;17:6000-6011.

15. Baek S, Choi CM, Ahn SH, et al. Exploratory clinical trial of $(4 S)-4-\left(3-\left[{ }^{18} \mathrm{~F}\right]\right.$ fluoropropyl)-L-glutamate for imaging $\mathrm{x}_{\mathrm{C}}{ }^{-}$transporter using positron emission tomography in patients with non-small cell lung or breast cancer. Clin Cancer Res. 2012;18:5427-5437.

16. Baek S, Mueller A, Lim YS, et al. (4S)-4-(3- ${ }^{18}$ F-fluoropropyl)-L-glutamate for imaging of $\mathrm{x}_{\mathrm{C}}{ }^{-}$transporter activity in hepatocellular carcinoma using PET: preclinical and exploratory clinical studies. J Nucl Med. 2013;54:117-123.

17. Bräuner-Osborne H, Slok FA, Skjaerbaek N, et al. A new highly selective metabotropic excitatory amino acid agonist: 2-amino-4-(3-hydroxy-5-methylisoxazol-4-yl)butyric acid. J Med Chem. 1996;39:3188-3194.

18. Julio-Pieper M, Flor PJ, Dinan TG, Cryan JF. Exciting times beyond the brain: metabotropic glutamate receptors in peripheral and non-neural tissues. Pharmacol Rev. 2011;63:35-58.

19. Ganapathy V, Thangaraju M, Prasad PD. Nutrient transporters in cancer: relevance to Warburg hypothesis and beyond. Pharmacol Ther. 2009;121:29-40.
20. Ahmadian H, Nielsen B, Brauner-Osborne H, et al. $(S)$-homo-AMPA, a specific agonist at the mGlu6 subtype of metabotropic glutamic acid receptors. J Med Chem. 1997;40:3700-3705.

21. Lo M, Ling V, Low C, Wang YZ, Gout PW. Potential use of the anti-inflammatory drug, sulfasalazine, for targeted therapy of pancreatic cancer. Curr Oncol. 2010;17:9-16.

22. Narang VS, Pauletti GM, Gout PW, Buckley DJ, Buckley AR. Suppression of cystine uptake by sulfasalazine inhibits proliferation of human mammary carcinoma cells. Anticancer Res. 2003;23:4571-4579.

23. Gout PW, Buckley AR, Simms CR, Bruchovsky N. Sulfasalazine, a potent suppressor of lymphoma growth by inhibition of the $\mathrm{x}_{\mathrm{c}}{ }^{-}$cystine transporter: a new action for an old drug. Leukemia. 2001;15:1633-1640.

24. Gout PW, Simms CR, Robertson MC. In vitro studies on the lymphoma growthinhibitory activity of sulfasalazine. Anticancer Drugs. 2003;14:21-29.

25. Chung WJ, Lyons SA, Nelson GM, et al. Inhibition of cystine uptake disrupts the growth of primary brain tumors. J Neurosci. 2005;25:7101-7110.

26. Ogunrinu TA, Sontheimer H. Hypoxia increases the dependence of glioma cells on glutathione. J Biol Chem. 2010;285:37716-37724.

27. Yoshikawa M, Tsuchihashi K, Ishimoto T, et al. xCT inhibition depletes CD44vexpressing tumor cells that are resistant to EGFR-targeted therapy in head and neck squamous cell carcinoma. Cancer Res. 2013;73:1855-1866.

28. Doxsee DW, Gout PW, Kurita T, et al. Sulfasalazine-induced cystine starvation: potential use for prostate cancer therapy. Prostate. 2007;67:162-171.

29. Guan J, Lo M, Dockery $\mathrm{P}$, et al. The $\mathrm{x}_{\mathrm{c}}{ }^{-}$cystine/glutamate antiporter as a potential therapeutic target for small-cell lung cancer: use of sulfasalazine. Cancer Chemother Pharmacol. 2009;64:463-472.

30. Lo M, Ling V, Wang YZ, Gout PW. The $\mathrm{x}_{\mathrm{c}}{ }^{-}$cystine/glutamate antiporter: a mediator of pancreatic cancer growth with a role in drug resistance. Br J Cancer. 2008;99:464-472.

31. Müerköster S, Arlt A, Witt M, et al. Usage of the NF-kappaB inhibitor sulfasalazine as sensitizing agent in combined chemotherapy of pancreatic cancer. Int J Cancer. 2003;104:469-476.

32. Chen RS, Song YM, Zhou ZY, et al. Disruption of xCT inhibits cancer cell metastasis via the caveolin-1/beta-catenin pathway. Oncogene. 2009;28:599-609.

33. Ishimoto T, Nagano O, Yae T, et al. CD44 variant regulates redox status in cancer cells by stabilizing the $\mathrm{xCT}$ subunit of system $\mathrm{x}_{\mathrm{c}}{ }^{-}$and thereby promotes tumor growth. Cancer Cell. 2011;19:387-400.

34. Gupta V, Jani JP, Jacobs S, et al. Activity of melphalan in combination with the glutathione transferase inhibitor sulfasalazine. Cancer Chemother Pharmacol. 1995;36:13-19.

35. Qin S, Colin C, Hinners I, Gervais A, Cheret C, Mallat M. System $\mathrm{X}_{\mathrm{c}}{ }^{-}$and apolipoprotein $\mathrm{E}$ expressed by microglia have opposite effects on the neurotoxicity of amyloid-beta peptide 1-40. J Neurosci. 2006;26:3345-3356.

36. Savaskan NE, Heckel A, Hahnen E, et al. Small interfering RNA-mediated xCT silencing in gliomas inhibits neurodegeneration and alleviates brain edema. Nat Med. 2008;14:629-632.

37. Domercq M, Sanchez-Gomez MV, Sherwin C, Etxebarria E, Fern R, Matute C. System $\mathrm{x}_{\mathrm{c}}{ }^{-}$and glutamate transporter inhibition mediates microglial toxicity to oligodendrocytes. J Immunol. 2007;178:6549-6556.

38. Albrecht P, Lewerenz J, Dittmer S, Noack R, Maher P, Methner A. Mechanisms of oxidative glutamate toxicity: the glutamate/cystine antiporter system $\mathrm{x}_{\mathrm{c}}{ }^{-}$as a neuroprotective drug target. CNS Neurol Disord Drug Targets. 2010;9:373-382.

39. Kumar M, Mosci C, Keu KV, et al. Evaluation of the ${ }^{18} \mathrm{~F}$-labeled L-glutamate derivative ${ }^{18}$ F-FSPG (BAY 94-9392) in brain and head and neck cancer patients [abstract]. J Nucl Med. 2012;53(suppl):274P. 